\title{
Foliar application of silicon and the effect on wheat seed yield and quality ${ }^{1}$
}

\author{
Samantha Rigo Segalin², Caroline Huth², Thais D`Avila Rosa³, Diógenes Barella \\ Pahins $^{2}$, Liliane Marcia Mertz ${ }^{2 *}$, Ubirajara Russi Nunes², Thomas Newton Martin²
}

\begin{abstract}
Adequate nutrients for plants are important for increasing the yield and quality of the seeds produced. The objective of this study was to evaluate foliar fertilization with silicon in wheat and its effect on seed yield and physiological quality. Treatments consisted of two silicon dosages (three and six liters silicon per hectare) and the control (no silicon) and five wheat cultivars: OR "Quartzo", OR "Ônix", Fundacep "Linhagem”, Fundacep "Campo Real” and Fundacep "Horizonte”. The experimental design was randomized blocks with four replications. After physiological maturity, harvesting and threshing of the seeds were done manually. Seed samples were evaluated for yield and physiological quality from the germination test, first germination count, seedling dry weight, accelerated aging, electrical conductivity, 1000 seeds and hectoliter weights. The results showed that the foliar application of silicon at the dosages tested did not affect the yield and physiological quality of the seeds produced by the wheat cultivars.
\end{abstract}

Index terms: Triticum aestivum L., fertilization, seed vigor.

\section{Aplicação foliar de silício e alterações no rendimento e na qualidade de sementes de trigo}

\begin{abstract}
RESUMO - A disponibilidade adequada de nutrientes às plantas é de fundamental importância tanto para incrementos em rendimento bem como, para a produção de sementes de elevada qualidade. Dessa forma, objetivou-se com esse trabalho avaliar o efeito da adubação foliar com silício em trigo, no rendimento e na qualidade fisiológica das sementes produzidas. Os tratamentos consistiram de duas doses de silício aplicados via foliar (três e seis litros de silício por hectare), além da testemunha (sem aplicação do produto). Foram utilizadas cinco cultivares de trigo (OR "Quartzo", OR “Ônix”, Fundacep "Linhagem”, Fundacep "Campo Real" e Fundacep "Horizonte"). O delineamento experimental foi blocos ao acaso, com quatro repetições. Após a maturidade fisiológica, efetuou-se a colheita e a debulha das sementes de forma manual. Posteriormente, as amostras foram encaminhadas ao laboratório de análise de sementes onde foram efetuadas as avaliações do rendimento e da qualidade das sementes, por meio dos testes de germinação, primeira contagem da germinação, massa seca de plântulas, envelhecimento acelerado, condutividade elétrica, massa de mil sementes e massa hectolitro. A aplicação de silício, nas cultivares de trigo e nas doses testadas, não afeta o rendimento nem a qualidade fisiológica das sementes produzidas.
\end{abstract}

Termos para indexação: Triticum aestivum L., nutrição, vigor de sementes.

\section{Introduction}

Wheat is the second most produced cereal in the world and is important in the global agricultural economy. The crop is grown in the South, Southeast and Centre-west regions of Brazil, producing $5.8 \mathrm{mmT}$ on around $2.1 \mathrm{~mm}$ ha (CONAB, 2012). Wheat consumption is projected to increase by $1.31 \%$ per year but internal production is still less than the domestic demand (MAPA, 2012). One of the factors which contribute

${ }^{1}$ Submitted on $04 / 13 / 2012$. Accepted for publication on 09/28/2012. ${ }^{2}$ Departamento de Fitotecnia, Universidade Federal de Santa Maria, 97105-900 Santa Maria, RS, Brasil. to productivity increases is the use of high quality seed and considering that certified seed use is currently around $70 \%$, there is an annual demand of $200,000 \mathrm{~T}$ of wheat seed (ABRASEM, 2011).

The production of low quality seeds is a chronic problem for the seed industry (Grisi et al., 2009). Innumerable factors may influence the yield and final quality of seeds produced, including crop management, the production environment (Nakagawa et al., 2004), the cultivars (Coventry et al., 2011)

${ }^{3}$ Departamento de Agronomia, Universidade Federal de Pelotas, Caixa Postal 354, 96001-970 - Pelotas, RS, Brasil.

*Corresponding author <lilianemertz@yahoo.com.br.> 
and the quality of the seeds planted (Lima et al., 2006). The adequate availability of nutrients is also essential for providing ideal crop conditions since the nutritional condition of plants affects the quality of the seeds they produce (Dornbos Júnior, 1995).

Crop demand for nutrients is generally more intense at the start of reproduction, being critical at seed formation, when considerable amounts of nutrients are translocated to seeds (Teixeira et al., 2005). Adequate nutrient availability benefits embryo formation and also the accumulation of seed reserves, not only contributing to yield increase but also to seed vigor and physiological quality. In black oats, studies with nitrogen fertilizer improved the productivity and quality of the seeds produced (Schuch et al., 1999; Nakagawa et al., 2000).

Among the factors which may influence seed quality is silicon, which although not considered an essential element for plant development, results in significant effects in agriculture since this micronutrient reduces various stress factors suffered by the plant, both biotic and abiotic (Carvalho et al., 2009). Among the advantages of using silicon in agriculture are a reduction in water stress, since this element reduces transpiration; an increase in photosynthetic efficiency, by maintaining the leaves more erect and rigid and with more light interception; and an increase in resistance to diseases, pests, the cold, salinity and toxicity caused by an excess of Al, Mn and Fe. Many of these benefits are attributed to a layer of silicon accumulating beneath the cuticle (Epstein, 1999; Mauad et al., 2003).

The capacity to absorb silicon varies with different plant species. In rice, wheat and barley, its absorption is an active process (Rains et al., 2006), whereas in sunflower it is absorbed both actively and passively, depending on its external concentration (Liang et al., 2006). However, there are few studies relating plant fertilization and nutrition to the quality of the seeds produced and in the case of elements such as silicon, the situation is even more critical. There is also commercial pressure to make silicon-based products available, arguing that there are benefits to crops but experimental results to support any benefits in wheat are lacking.

The objective of this study was to evaluate the effect of foliar fertilization with silicon in wheat on the yield and physiological quality of the seeds produced.

\section{Material and Methods}

This study was done at the experimental area of the Department of Plant Science, Federal University of Santa Maria, Santa Maria - Rio Grande do Sul State, Brazil, in the Central Depression climate region at an altitude of $95 \mathrm{~m}$, latitude $29^{\circ} 42^{\prime} 24^{\prime \prime} \mathrm{S}$ and longitude $53^{\circ} 48^{\prime} 42^{\prime \prime} \mathrm{W}$. According to Köppen's classification, the main climate is high humid tropical (Cwa) (Moreno, 1961). The soil belongs to the São Pedro mapping unit, being classified under the Brazilian Soil Classification System as a Red, Sandy, Dystrophic Argisol (Embrapa, 2006).

The experiment was installed on soybean residues (2010/2011 crop) and the weeds, pests and diseases were managed according to recommendations made by the Meeting of the Brazilian Commission for Wheat and Triticale Research, 2011 (RCBPT, 2011). The wheat was sown on June $10^{\text {th }}, 2011$, using 410 viable seeds per $\mathrm{m}^{2}$. Fertilization was done according to the soil analysis results using a base formulation of $300 \mathrm{~kg} \cdot \mathrm{ha}^{-1}$ of a 5-30-20 fertilizer formula. Topdressing was a nitrogen application (urea, $45 \% \mathrm{~N}$ ) in the tillering stage ( $90 \mathrm{~kg}$ of N.ha- $\left.{ }^{-1}\right)$ split between the start of tillering and full tillering.

The experimental design used were randomized blocks with four replications and the treatments were organized in a factorial (five cultivars and three dosages of silicon). Cultivars used were: OR "Quartzo", OR “Ônix”, Fundacep "Linhagem”, Fundacep "Campo Real" and Fundacep "Horizonte" and the dosages of silicon applied were 0 (control - no application), three and six liters of product per ha. Each experimental block consisted of 11 rows, $2.5 \mathrm{~m}$ long with $0.2 \mathrm{~m}$ spacing between rows.

The silicon applications were applied on the leaves with a backpack sprayer with the silicon dosages ( 3 and 6 L.ha $^{-1}$ ) split respectively into three applications of 1 and $2 \mathrm{~L}^{-h^{-1}}{ }^{-1}$, at three different stages of development according to the Feeks scale (Large, 1954): tillering stage: stage 3 (tillers formed); elongation: stage 8 (last leaf appears) and anthesis: stage 10.1 (ear formation).

After the physiological maturation of the seeds $(05 / 11 / 2011)$, an area of the block $\left(5.5 \mathrm{~m}^{2}\right)$ was manually harvested. Seed yields were adjusted to $13 \%$ moisture content. The samples were taken to the Seed Research Laboratory of the Plant Science Department of the Federal University of Santa Maria, to determine seed physiological quality using the following tests: (i) Germination: four replications of 200 seeds, sown in germitest paper rolls, moistened with 2.5 times the weight of the dry paper and kept in a germinator at $20^{\circ} \mathrm{C}$. The evaluations were made at four (first count) and seven days after the start of the test, as set out in the Seed Analysis Rules - RAS (Brasil, 2009), with results expressed as a percentage of normal seedlings; (ii) First germination count: done at the same time as the germination test, determining the mean percentage of normal seedlings, four days after the beginning of the test. The results were expressed as a percentage of normal seedlings. (iii) Seedling dry weight: after measuring seedling length, these were cut, separating the aerial part from the roots. The material was then placed in aluminium capsules 
and kept in a forced air convection oven at $80{ }^{\circ} \mathrm{C}$ for $24 \mathrm{~h}$. Dry plant weight was measured using a precision balance $(0.0001 \mathrm{~g})$ and the results were expressed in grams. (iv) Accelerated aging test: done in a gerbox-type plastic box adapted with mesh, with $40 \mathrm{~mL}$ of distilled water added. The seeds were placed on the mesh having no contact with the water. The boxes were closed and taken to an incubating oven for 48 hours, at a temperature of $42{ }^{\circ} \mathrm{C}$, maintaining the relative humidity close to $100 \%$. The seeds were then sown as previously described for germination, with four replications of 200 seeds per treatment, with evaluations made four days after the beginning of the test; $(v)$ Electrical conductivity: with four replications of 50 weighed seeds, which were immersed in $75 \mathrm{~mL}$ of deionized water. The samples were stored at $20{ }^{\circ} \mathrm{C}$ for 24 hours after which the electrical conductivity of the immersion solution was read and the results expressed in $\mu \mathrm{S} . \mathrm{cm}^{-1} \cdot \mathrm{g}^{-1}$ seed; (vi) 1000 seed weight: with four replications of eight subsamples of 100 seeds as described in RAS (Brasil, 2009) and (vii) Hectoliter weight: the weight of $100 \mathrm{~L}$, expressed in kilos per hectoliter $\left(\mathrm{Kg} . \mathrm{hL}^{-1}\right)$ was determined, using a specific gravity balance according to the methodology described in RAS (Brasil, 2009).

The results in percentages were transformed into arcsine $\sqrt{x / 100}$ in order to comply with the premises of the analysis of variance, where $x$ represents the percentage of normal seedlings obtained from the tests. The means were compared by the Scott- Knott test at the 5\% probability level. Sisvar software was used for the statistical analyses (Ferreira, 2008).

\section{Results and Discussion}

The experiment was not affected by weeds, pests or diseases due to preventive chemical control measures. The analysis of variance (Table 1) shows that for the first count, accelerated aging and 1000 seed weight, the block effect was significant, indicating heterogeneous blocks and that the use of randomized blocks was a correct decision. However, for germination, dry weight, electrical conductivity, hectoliter weight and seed production, the blocks were not heterogeneous. Although the non-significance of block effects in most tests demonstrated the suitability of a completely randomized experimental design, according to Cargnelutti Filho and Guadagnin (2011), the use of blocks should be a priority in order to guarantee control of the sources of heterogeneity when present.

Table 1. Summary of the analysis of variance for the parameters evaluated for different cultivars of wheat seed fertilized with silicon: germination (G, \%), first count (FC, \%), dry weight (DW, g), accelerated aging (AA, \%), mass electrical conductivity (EC, $\mu \mathrm{S} . \mathrm{cm}^{-1}$. $\left.\mathrm{g}^{-1}\right), 1000$ seed weight (TSW, g), hectoliter weight $\left(\mathrm{HW}, \mathrm{kg} . \mathrm{hL}^{-1}\right)$ and seed production $\left(\mathrm{SP}, \mathrm{t} . \mathrm{ha}^{-1}\right)$.

\begin{tabular}{|c|c|c|c|c|c|}
\hline \multirow{2}{*}{ FV } & \multicolumn{5}{|c|}{ Mean Squares } \\
\hline & GL & $\mathrm{G}(\%)$ & $\mathrm{FC}$ & DW & AA \\
\hline Blocks & 3 & 4.57 & $486.25 *$ & 0.0002 & $232.9 *$ \\
\hline Cultivars (A) & 4 & $14.23 *$ & $76.88^{*}$ & $0.0003 *$ & $222.8 *$ \\
\hline Silicon (D) & 2 & 0.14 & 11.10 & 0.0003 & 181.14 \\
\hline A x D & 8 & 2.22 & 350.37 & 0.0002 & 45.16 \\
\hline Residual & 42 & 4.93 & 975.73 & 0.0002 & 34.44 \\
\hline CV (\%) & & 2.33 & 5.47 & 11.30 & 6.72 \\
\hline Mean & & 95 & 88 & 0.1280 & 87 \\
\hline \multirow{2}{*}{ FV } & \multicolumn{5}{|c|}{ Mean Squares } \\
\hline & GL & $\mathrm{EC}$ & TSW & HW & SP \\
\hline Blocks & 3 & 63.24 & $40.35^{*}$ & 0.539 & 321.06 \\
\hline Cultivars (A) & 4 & $123.8^{*}$ & $56.96^{*}$ & 7.102 & $580.2 *$ \\
\hline Silicon (D) & 2 & 2.12 & 6.74 & 1.122 & 333.83 \\
\hline A x D & 8 & 4.53 & 4.27 & 1.579 & 94.75 \\
\hline Residual & 42 & 23.77 & 11.03 & 1.739 & 186.09 \\
\hline CV (\%) & & 22.44 & 10.25 & 1.69 & 13.64 \\
\hline Mean & & 21.73 & 32.39 & 78.19 & 3.162 \\
\hline
\end{tabular}

*Significant at the $5 \%$ level of probability according to the $\mathrm{F}$ test.

The cultivar $\mathrm{x}$ silicon dosage interaction was not significant showing that cultivar behavior is independent of the silicon dosage used (Table 1). There was a significant effect for the cultivar factor, demonstrating that cultivars show distinct behaviors for the variables evaluated, except for the first germination count, seedling dry weight and hectoliter weight. 
Data on seed quality are shown in Table 2 and independently of the cultivar or treatment used, the seeds produced had a higher percentage germination than that required for wheat seed $(80 \%)$, as established in Normative Instruction $n^{\circ} 25$, of December $16^{\text {th }}$,
2005 (MAPA, 2011). The minimum percentage in the germination test was $94 \%$ and even after the seeds were stressed by accelerated aging, they still maintained a minimum $81 \%$ of normal seedlings (Table 2), demonstrating the high quality of the seeds obtained.

Table 2. Mean of parameters evaluated for different cultivars of wheat seeds: germination (G, \%), first count (FC, \%), dry weight

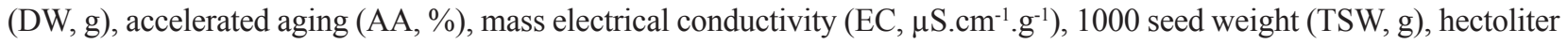
weight $\left(\mathrm{HW}, \mathrm{kg} . \mathrm{hL}^{-1}\right)$ and seed production $\left(\mathrm{SP}, \mathrm{t}_{\mathrm{ha}} \mathrm{h}^{-1}\right)$.

\begin{tabular}{|c|c|c|c|c|c|c|c|c|}
\hline Cultivar & G & $\mathrm{FC}$ & DW & AA & $\mathrm{EC}$ & TSW & HW & SP \\
\hline Quartzo & $95 \mathrm{~b}$ & 87 & 0.135 & $90 \mathrm{a}$ & $21.37 \mathrm{a}$ & $35.27 \mathrm{a}$ & $77.08 \mathrm{~b}$ & $3.31 \mathrm{a}$ \\
\hline Ônix & $95 \mathrm{~b}$ & 87 & 0.121 & $86 \mathrm{~b}$ & $25.11 \mathrm{~b}$ & $29.67 \mathrm{~b}$ & $78.70 \mathrm{a}$ & $2.83 \mathrm{~b}$ \\
\hline Linhagem & $94 \mathrm{~b}$ & 89 & 0.126 & $92 \mathrm{a}$ & $24.91 \mathrm{~b}$ & $30.87 \mathrm{~b}$ & $78.30 \mathrm{~b}$ & $3.06 \mathrm{~b}$ \\
\hline Campo Real & $96 a$ & 88 & 0.130 & $88 \mathrm{a}$ & $18.31 \mathrm{a}$ & $33.03 \mathrm{a}$ & $77.80 \mathrm{~b}$ & $3.38 \mathrm{a}$ \\
\hline Horizonte & $97 \mathrm{a}$ & 90 & 0.126 & $81 \mathrm{~b}$ & $18.92 \mathrm{a}$ & $33.14 \mathrm{a}$ & $79.05 \mathrm{a}$ & $3.22 \mathrm{a}$ \\
\hline Mean & 95 & 88 & 0.128 & 87 & 22.44 & 32.39 & 78.2 & 3.16 \\
\hline $\mathrm{CV}(\%)$ & 2.33 & 5.47 & 11.30 & 6.72 & 21.73 & 10.25 & 1.69 & 13.63 \\
\hline
\end{tabular}

*Means followed by the same letter in the column do not differ among themselves according to the Scott- Knott test, $\mathrm{p}>0.05$. Coefficient of variation percentage (CV, \%).

The classification of cultivars at germination was different from that obtained in the other vigor tests (accelerated aging and electrical conductivity) (Table 2), with the Quartzo and Campo Real cultivars showing a better physiological quality. This difference may be explained by the fact that the germination test is done under ideal conditions of humidity, temperature and substrate (Lima et al., 2006), where differences in genotype performance may not be expressed.

These data agree with studies by Fanan et al. (2006), Lima et al. (2006) and Maia et al. (2007), who declared that the accelerated aging test is suitable for evaluating wheat seed vigor. The same can be said for electrical conductivity, since according to Biaggioni et al. (2007) this test is efficient for ranking wheat seed lots with different vigor levels, besides being quick compared to other vigor tests, since it detects the start of the process of seed membrane deterioration.

On the other hand, tests for the first germination count and seedling dry weight showed no significant differences between cultivars. These data agree with those of Battisti et al. (2011), who showed that tests based on seedling performance (length and dry weight) do not provide a reliable evaluation of wheat seed physiological quality.

The cultivars which had a greater 1000 seed weight were Quartzo, Campo Real and Horizonte, with the latter performing worse in the accelerated aging test compared to the others. Thus, it can be inferred that heavier seeds do not always show a higher vigor. This agrees with Costa et al. (2004), who found that seed size in soybeans had no influence on their physiological quality.

The Horizonte and Ônix cultivars gave better results for the hectoliter weight, whereas the rest gave poorer results. This behavior was different to that obtained from the accelerated aging and electrical conductivity tests, demonstrating that the hectoliter weight is not suitable for evaluating wheat seed vigor. These results disagree with those of Battisti et al. (2011), who believed that the hectoliter weight may be used as a quick test for evaluating wheat seed physiological quality even though these same authors declare that this test should be complemented with other vigor tests.

The cultivars Quartzo, Campo Real and Horizonte gave higher yields for seed production (Table 2).

The means of the results for parameters evaluated for different silicon dosages showed that there were no differences in the yield or quality of the seeds produced (Table 3), although the positive effects on seed quality of fertilizing with silicon have been described by some authors. Calcium silicate applied to soils with low silicon levels at the beginning of rice planting had a positive effect on the quality of seeds produced (Vieira et al., 2011). Toledo et al. (2011) working with silicon fertilization in common oats, recorded a linear increase in the first germination count and a decrease in electrical conductivity at the highest dosages, indicating the production of higher quality seed. However, silicon appears to influence other characteristics, such as pathogen suppression (Rodrigues and Datnoff, 2005), and tolerance to stress (Korndörfer and Pereira, 2002), instead of germination and vigor, which are indirectly affected.

Different dosages of silicon also had no measurable effects on seed production and mean productivity was 3.16 t. ha ${ }^{-1}$. These results agree with those of Marchesan et al. (2004), who observed no yield increases after applying silicon in irrigated rice and with those of Freitas et al. (2011), who saw no increases in corn production with the foliar application of silicon. Therefore, crops growing under favorable conditions 
and free of pathogens can produce seed with a high physiological quality and higher yields without silicon fertilization because this element is not considered essential for plant growth even though its absorption offers various benefits (Mauad et al., 2003).

Table 3. Mean of parameters evaluated for wheat seeds produced by fertilizing with different silicon dosages: germination (G, \%), first count (FC, \%), dry weight (DW, g), accelerated aging (AA, \%), mass electrical conductivity (EC, $\left.\mu \mathrm{S} . \mathrm{cm}^{-1} \cdot \mathrm{g}^{-1}\right), 1000$ seed weight (TSW, g), hectoliter weight $\left(\mathrm{HW}, \mathrm{kg} \mathrm{hL}^{-1}\right)$ and seed production $\left(\mathrm{SP}, \mathrm{t} . \mathrm{ha}^{-1}\right)$.

\begin{tabular}{cccccccccc}
\hline Dosages $\left(\mathrm{L} \mathrm{ha}^{-1}\right)$ & G & FC & DW & AA & EC & TSW & HW & SP \\
\hline 0 & 95 & 89 & 0.126 & 86 b & 21.65 & 32.49 & 78.47 & 3,071 \\
3 & 95 & 88 & 0.125 & $91 \mathrm{a}$ & 21.45 & 32.92 & 78.07 & 3,106 \\
6 & 95 & 88 & 0.132 & $86 \mathrm{~b}$ & 22.08 & 31.77 & 78.05 & 3,310 \\
\hline
\end{tabular}

* Means followed by the same letter in the column do not differ among themselves according to the Scott- Knott test, $p>0.05$.

\section{Conclusion}

The foliar application of silicon in wheat at the dosages tested did not affect the yield and quality of the seeds produced.

\section{References}

ABRASEM. Associação Brasileira de Sementes e Mudas. Anuário 2011 Agricultura sem fronteiras, 2011. 86p.

BATTISTI, R.; SOMAVILLA, L.; BUSANELLO, C.; SCHWERZ, L. Eficiência do uso da massa hectolitro como teste rápido de vigor de semente de trigo (Triticum aestivum). Revista da FZVA, v.18, n.1, p.125-135, 2011. http:// revistaseletronicas.pucrs.br/ojs/index.php/fzva/article/viewfile/8605/6866

BIAGGIONI, M.A.M.; YANAGIWARA, R.S.; CAVARIANI, C.; TARGA, L.A. Análise de acidez graxa em sementes de trigo (Triticum aestivum L.). Bioscience Journal, v.23, n.1, p.22-28, 2007. http://www.seer.ufu.br/index. $\mathrm{php} / \mathrm{biosciencejournal} /$ article/view/6380

BRASIL. Ministério da Agricultura, Pecuária e Abastecimento. Regras para análise de sementes. Ministério da Agricultura, Pecuária e Abastecimento. Secretaria de Defesa Agropecuária. Brasília, DF: MAPA/ACS, 2009. 395p. http://www.agricultura.gov.br/arq_editor/file/laborat $\%$ c $3 \%$ b3rio/sementes/ regras $\% 20$ para $\% 20$ analise $\% 20 \mathrm{de} \% 20$ sementes.pdf

CARGNELUTTI FILHO, A.; GUADAGNIN, J. Planejamento experimental em milho. Revista Ciência Agronômica, v.42, n.4, p.9-1016, 2011. http:// www.scielo.br/pdf/rca/v42n4/a25v42n4.pdf

CARVALHO, M.P.; JÚNIOR, L.A.Z.; GROSSI, J.A.S.; BARBOSA, G.J. Silício melhora produção e qualidade do girassol ornamental em vaso. Ciência Rural, v.39, n.8, p.2394-2399, 2009. http://www.scielo.br/pdf/cr/v39n8/a333cr1515.pdf

CONAB. Companhia Nacional de Abastecimento. Acompanhamento de safra brasileira: grãos, quarto levantamento, safra 2011/2012. 2012. 38p. http://www.conab.gov.br/olalacms/uploads/arquivos/120110105302boletimg raos4olevantamento.pdf. Acesso em: 30 mar. 2012.

COSTA, P.R.; CUSTÓDIO, C.C.; MACHADO NETO, N.B.; MARUBAYASHI, O.M. Estresse hídrico induzido por manitol em sementes de soja de diferentes tamanhos. Revista Brasileira de Sementes, v.26, n.1, p.105-113, 2004. http://www.scielo.br/pdf/rbs/v26n2/24496.pdf

COVENTRY, D.R.; GUPTA, R.K.; YADAV, A.; POSWAL, R.S.; CHHOKAR, R.S.; SHARMA, R.K.; YADAV, V.K.; GILL, S.C.; KUMAR, A.; MEHTA, A.; KLEEMANN, S.G.L.; BONAMANO, A.; CUMMINS, J.A. Wheat quality and productivity as affected by varieties and sowing time in Haryana, India. Field Crops Research, v.123, p.214-225, 2011. http://www.sciencedirect.com/science/ journal/03784290/123/3

DORNBOS JUNIOR, D.L. Production environment and seed quality. In: BASRA, A.S. (Ed.). Seed quality: basic mechanisms and agricultural implications. New York: Food Products Press, p.119-152, 1995.

EMBRAPA. Empresa Brasileira de Pesquisa Agropecuária. Sistema Brasileiro de Classificação de Solos. 2.ed. Rio de Janeiro: Embrapa Solos, 2006. 306 p. http://ag20.cnptia.embrapa.br/repositorio/livro+sbcs2-ed000fzv hmj5j02wx5ok0q43a0rx9wj0bm.pdf

EPSTEIN, E. Silicon. Annual Review of Plant Physiology and Plant Molecular Biology, v.50, n.1, p.641- 664, 1999. http://www.annualreviews. org/doi/pdf/10.1146/annurev.arplant.50.1.641

FANAN, S.; MEDINA, P.F.; LIMA, T.C.; MARCOS-FILHO, J. Avaliação do vigor de sementes de trigo pelos testes de envelhecimento acelerado e de frio. Revista Brasileira de Sementes, v.28, n.2, p.152-158, 2006. http://www. scielo.br/pdf/rbs/v28n2/a21v28n2.pdf

FERREIRA, D.F. Sisvar: um programa para análises e ensino de estatística. Revista Symposium, v. 6, p.36-41, 2008. http://www.fadminas.org.br/ symposium/12edicoes/artigo5.pdf

FREITAS, L. B.; COELHO, E. M.; MAIA, S. C. M.; SILVA, T. R. B. Adubação foliar com silício na cultura do milho. Revista Ceres, v.58, n.2, p.262-267, 2011. http://www.scielo.br/pdf/rceres/v58n2/a20v58n2.pdf

GRISI, P.U.; SANTOS, C.M.; FERNANDES, J.J.; JÚNIOR, A.A. Qualidade de sementes de girassol tratadas com inseticidas e fungicidas. Bioscience Journal, v.25, n.4, p.28-36, 2009. http://sumarios.org/sites/default/files/pdfs/301313951.pdf

KORNDÖRFER, G.H.; PEREIRA, H. S. O silício e a tolerância ao estresse. Revista Citricultura Atual, v.4, n. 26, p.12-13, 2002. http://www.dpv24.iciag. ufu.br/silicio/arquivos\%20papers/rev.citric.atual\%202002\%20-\%20si $\% 20$ x\%20estresse \%204\%2826\%2912-13.pdf

LARGE, E.C. Growth stages in cereals. Illustration of the Feekes scale. Plant Pathology, v.3, n.4, p.128-129, 1954. http://onlinelibrary.wiley.com/ doi/10.1111/j.1365-3059.1954.tb00716.x/pdf

LIANG, Y.; HUA, H.; ZHU, Y.; CHENG, C.; ROMHELD, V. Importance of plant species and external silicon concentration to active silicon uptake and transport. New Phytologist, v.172, n.1, p.63-72, 2006. http://www3. interscience.wiley.com/cgi-bin/fulltext/118627318/pdfstart

LIMA, T.C.; MEDINA, P.F.; FANAN, S. Avaliação do vigor de sementes de trigo pelo teste de envelhecimento acelerado. Revista Brasileira de Sementes, 
v.28, n.1, p.106-113, 2006. http://www.scielo.br/pdf/rbs/v28n1/a15v28n1.pdf

MAIA, A.R.; LOPES, J.C.; TEIXEIRA, C.O. Efeito do envelhecimento acelerado na avaliação da qualidade fisiológica de sementes de trigo. Ciência e Agrotecnologia, v.31, n.3, p.678-684, 2007. http://www.scielo.br/pdf/cagro/ v31n3/a12v31n3.pdf

MAPA - Ministério da Agricultura, Pecuária e Abastecimento. http://www. agricultura.gov.br/vegetal/culturas/trigo. Acesso em: 21 mar. 2012.

MAPA. Ministério da Agricultura, Pecuária e Abastecimento. Instrução Normativa $\mathrm{N}^{\circ} 25$, de 16 de dezembro de 2005. Anexo XII - Padrões para produção e comercialização de sementes de trigo e de trigo duro. http://www.agricultura. pr.gov.br/arquivos/file/pdf/padroes_trigo.pdf. Acesso em: 19 mar. 2011.

MARCHESAN, E.; VILLA, S.C.C.; MARZARI, V.; KORNDORFER, G.H.; SANTOS, M. Aplicação de silício em arroz irrigado: efeitos nos componentes da produção. Bioscience Journal, v.20, n.3, p.125-131, 2004. http://www. seer.ufu.br/index.php/biosciencejournal/article/view/6550/4284

MAUAD, M.; CRUSCIO, C.A.C.; FILHO, H.G.; CORRÊA, J.C. Nitrogen and silicon fertilization of upland rice. Scientia Agrícola, v.60, n.4, 2003. http://www.scielo.br/pdf/sa/v60n4/a23v60n4.pdf

MORENO, J.A. Clima do Rio Grande do Sul. Porto Alegre, Secretaria da Agricultura, 1961. 42p.

NAKAGAWA, J.; CAVARIANI, C.; CASTRO, M.M. Armazenamento de sementes de aveia preta produzidos em solos de diferentes fertilidades. Revista Brasileira de Sementes, v.26, n.2, p.7-14, 2004. http://www.scielo.br/ $\mathrm{pdf} / \% 0 \mathrm{~d} / \mathrm{rbs} / \mathrm{v} 26 \mathrm{n} 2 / 24483 . \mathrm{pdf}$

NAKAGAWA, J.; CAVARIANI, C.; MACHADO, J.R. Adubação nitrogenada no perfilhamento da aveia-preta em duas condições de fertilidade do solo. Pesquisa Agropecuária Brasileira, v.35, n.6, p.1071-1080, 2000. http://www. scielo.br/pdf/\%0d/pab/v35n6/4661.pdf
RAINS, D.W.; EPSTEIN, E.; ZASOSKI, R.J.; ASLAM, M. Active silicon uptake by wheat. Plant and Soil, The Hague, v.280, n.1-2, p.223-228, 2006. http://www.springerlink.com/content/0xm6233224679p42/

REUNIÃO DA COMISSÃO BRASILEIRA DE PESQUISA DE TRIGO E TRITICALE, 4., 2011, Cascavel, PR. Informações técnicas para Trigo e Triticale - safra 2011. 2011. 171p. http://www.cnpt.embrapa.br/culturas/ trigo/informacoestecnicastrigotriticale_safra_2011.pdf

RODRIGUES, F.A.; DATNOFF, L.E. Silicon and rice disease management. Fitopatologia Brasileira, v.30, n.5, p.457-469, 2005. http://www.scielo.br/ $\mathrm{pdf} / \mathrm{fb} / \mathrm{v} 30 \mathrm{n} 5 / 26141$.pdf

SCHUCH, L.O.B.; NEDEL, J.L.; MAIA, M.S.; ASSIS, F.N. Vigor de sementes e adubação nitrogenada em aveia preta (Avena strigosa Schreb.). Revista Brasileira de Sementes, v.21, n.2, p.127-134, 1999. http://www. abrates.org.br/revista/artigos/1999/v21n2/artigo19.pdf

TEIXEIRA, I.R.; BORÉM, A.; ARAÚJO, G.A.A., ANDRADE, M.J.B. Teores de nutrientes e qualidade fisiológica de sementes de feijão em resposta à adubação foliar com manganês e zinco. Bragantia, v.64, n.1, p.83-88, 2005. http://www.scielo.br/pdf/\%0d/brag/v64n1/23855.pdf

TOLEDO, M.Z.; GARCIA, R.A.; MERLIN, A.; FERNANDES, D.M. Seed germination and seedling development of white oat affected by silicon and phosphorus fertilization. Scientia Agricola, v.68, n.1, p.18-23, 2011. http://www. scielo.br/scielo.php?pid=S0103-90162011000100003\&script=sci arttext

VIEIRA, A.R.; OLIVEIRA, J.A.; GUIMARÃES, R.M.; CARVALHO, M.L.M.; PEREIRA, E. M.; CARVALHO, B.O. Qualidade de sementes de arroz irrigado produzidas com diferentes doses de silício. Revista Brasileira de Sementes, v.33, n.3, p.490-500, 2011. http://www.scielo.br/scielo. php?pid $=$ s0101-31222011000300012\&script $=$ sci_arttext 